\title{
Thermodynamic analysis of stability in iron removal from kaolin by using oxalic acid
}

\section{(Análise termodinâmica da estabilidade da remoção do ferro do caulim usando ácido oxálico)}

\author{
C. Ocampo-López, M. E. Ramírez-Carmona, E. Vélez-Ortiz \\ Facultad de Ingeniería Química, Universidad Pontificia Bolivariana, CIBIOT \\ Circular 1 ${ }^{a}$ No 70-01 Bloque 11 Campus Laureles, Medellín - Colombia \\ carlos.ocampo@upb.edu.co,margarita.ramirez@upb.edu.co,evortiz@unal.edu.co
}

\begin{abstract}
The graphical representation of global stability for a system, or Pourbaix diagram, was constructed to perform a thermodynamic study of iron removal from kaolin using oxalic acid as an oxidant. To do this the free energies of formation of the oxalate complex of the system were calculated, and it was found that the more stable specie is $\mathrm{Fe}\left(\mathrm{C}_{2} \mathrm{O}_{4}\right)_{3}^{3-}$, with a calculated free energy of formation of $-3753.88 \mathrm{kcal} / \mathrm{mol}$. Thermodynamic stability functions were estimated for the system as a function of $\mathrm{pH}$ and $\mathrm{E}_{\mathrm{h}} \mathrm{known}$ as potential of oxide reduction. It was built a global stability diagram for the removal system; it showed that the specie trioxalate $\mathrm{Fe}\left(\mathrm{C}_{2} \mathrm{O}_{4}\right)_{3}^{3-}$ is the only oxalate in equilibrium with other compounds associated with the removal of iron in kaolin.
\end{abstract}

Keywords: kaolin, iron removal, thermodynamic study, organic acids.

Resumo

A representação gráfica da estabilidade global de um sistema, ou diagrama Proubaix, foi construída para representar um estudo termodinâmico da remoção do ferro do caulim usando ácido oxálico como um oxidante. Para isso as energias livres de formação do complexo oxalato do sistema foram calculadas, e verificou-se que a espécie $\mathrm{Fe}\left(\mathrm{C}_{2} \mathrm{O}_{4}\right)_{3}^{3-}$ é a mais estável, com a energia livre de formação calculada $-3753,88 \mathrm{kcal} / \mathrm{mol}$. Funções de estabilidade termodinâmica foram estimadas para o sistema em função de pH e $E_{h}$ conhecido como potencial de oxido-redução. Foi construído um diagrama de estabilidade global para o sistema de remoção, que mostrou que a espécie trioxalato $\mathrm{Fe}\left(\mathrm{C}_{2} \mathrm{O}_{4}\right)_{3}^{3-}$ é o único em equilibrio com outros compostos associados com a remoção do ferro no caulim.

Palavras-chave: caulim, remoção de ferro, estudo termodinâmico, ácidos orgânicos.

\section{INTRODUCTION}

The acids most commonly used in traditional iron removal from kaolin in industrial scale are sulfuric acid and phosphoric [1-4]. Other authors reported experimental studies on iron removal which employs organic acids as oxalic acid and ascorbic [5, 6]. However it is considered that the oxalic acid presents a greater potential for removal of iron species, given their complexing behavior and their selectivity [7].

Studies performed by Lema [8], Cameselle [9] and Mesquita [10], suggest that the use of organic acids as oxidizing agents for the removal of iron in the kaolin are selective, obtaining efficiencies above $30 \%$ and using different operational conditions of $\mathrm{pH}$, temperature and pulp density [11, 12].

Thermodynamic aspects of iron removal from kaolin has been studied in a limited way, and are commonly applied under ideal conditions, since no data are available for calculating the global stabilities of the species involved in the removal process iron and the amount of physicochemical interactions occurring between the process variables $[13,14]$.
To simplify the analysis and generate a rapid compression of the behavior of systems for metals removal such as iron from minerals like kaolin, Pourbaix diagrams are traditionally used, it can be constructed in a theoretical way by calculating the overall stability such as reported by Fishtick [15-17].

This paper presents a study on the calculation of the global stability and development of a Pourbaix diagram of the species involved in the removal of iron in kaolin using oxalic acid

\section{METHODS}

Construction of stability diagrams for the species involved in iron removal from kaolin

For the thermodynamic study of iron removal from kaolin it was established the theoretical phase diagram of the related species in the process, or Pourbaix diagram $\left(\mathrm{E}_{\mathrm{h}}\right.$ $\mathrm{pH})$. It was proposed a calculation routine for the prediction of the thermodynamic stabilities of the compounds based 
on the Gibbs energy matrix systems using the methodology originally proposed by Fishtik [15]. In this methodology it was considered a system consisting of $n$ chemical species $B_{i}(i=1$, $2, \ldots n)$ at a fixed temperature of $25^{\circ} \mathrm{C}$ and a constant pressure of $101.3 \mathrm{kPa}$. Each species with a coefficient of activity $a_{i}(i=$ $1,2, \ldots n)$. It was defined $\bar{G}_{i}\left(T, P, a_{1}, \ldots, a_{n}\right)$ as partial Gibbs free energy for each species. By defining a matrix element $\epsilon_{i j}(i$ $=1, \ldots, n ; j=1, \ldots s)$ as the amount of elements $E_{j}(j=1, \ldots s)$ in the specie $B_{i}$, the following vectors were generated:

$$
\begin{aligned}
\boldsymbol{B} & =\left(B_{1}, B_{2}, \ldots, B_{n}\right)^{\mathrm{T}} \\
\boldsymbol{E} & =\left(E_{1}, E_{2}, \ldots, E_{n}\right)^{\mathrm{T}} \\
\overline{\mathbf{G}} & =\left(\overline{\mathrm{G}}_{l}, \overline{\mathrm{G}}_{2}, \ldots, \overline{\mathrm{G}}_{n}\right)^{\mathrm{T}}
\end{aligned}
$$

Where $\mathbf{B}=\epsilon \boldsymbol{E}$

$$
\text { Let define } \boldsymbol{\rho}=v \mathbf{B}=0
$$

as a vector of chemical reactions consisting of a linear combination of a stoichiometric coefficient matrix $v$, of dimensions $n \times m$, and vector B previously d escribed species, so that:

$$
\boldsymbol{\rho}=\left(\rho_{1}, \rho_{2}, \ldots, \rho_{\mathrm{m}}\right)^{\mathrm{T}}
$$

where $m$ represents the number of independent chemical reactions between species involved in the system.

According to chemical thermodynamics, the change in free energy of a thermodynamic system with chemical reactions was assessed by the expression:

$$
\Delta \mathbf{G}=v \overline{\mathbf{G}}
$$

where, for each reaction $\rho_{\mathrm{m}}$, the change in Gibbs free energy was given by

$$
\Delta \mathrm{G}_{\mathrm{j}}=\Delta \mathrm{G}_{\mathrm{j}}^{0}(\mathrm{~T}, \mathrm{P})+\mathrm{RT} \operatorname{In} \Pi_{\mathrm{i}=1}^{\mathrm{n}} \mathrm{a}_{\mathrm{i}}^{\mathrm{vij}}
$$

which is an implicit function of $\mathrm{pH}$ and redox potential $\mathrm{E}_{\mathrm{h}}$, given the functional relationship of the activity coefficient of $\mathrm{H}^{+}$ions and the transferred electrons during the progress of all reactions $\rho_{\mathrm{m}}$.

Thermodynamic stability was defined for each substance involved in the process as a vector of $n$ components in the form:

$$
\Sigma=v^{\mathrm{T}}\left(v v^{\mathrm{T}}\right)^{-1} \Delta \mathbf{G}
$$

$$
\text { With } \Sigma=\Sigma\left(\mathrm{T}, \mathrm{P}, \mathrm{pH}, \mathrm{E}_{\mathrm{h}}\right)
$$

Values of $\mathrm{pH}$ and $\mathrm{E}_{\mathrm{h}}$ at constant temperature and pressure that minimized the function $\Sigma$ and solved the equation:

$$
\left(\Sigma_{\mathrm{i}}-\Sigma_{\mathrm{j}}\right)=0
$$

for chemical species i, j, represented points of thermodynamic stability. Where both $\Sigma_{i}$ and $\Sigma_{j}$ must be negative and equal value. These set of values $\left(\mathrm{pH}, \mathrm{E}_{\mathrm{h}}\right)$ were plotted in a $2 \mathrm{D}$ chart, establishing the stability regions, and finally generating a stability diagram for the iron removal species in kaolin.

In order to solve the equations proposed in $(\mathrm{K})$, a calculating tool was developed in MATLAB (Mathworks).

\section{RESULTS AND DISCUSSION}

It was constructed a thermodynamic stability diagram to study the behavior of the process of iron removal from kaolin by using oxalic acid, as mentioned previously. A set of species relevant to the process were selected employing reported studies in the literature about iron removal reactions

\begin{tabular}{|c|c|c|}
\hline Specie & $\Delta \mathrm{G}_{\mathrm{f}}^{\mathrm{o}}(\mathrm{kcal} / \mathrm{mol})$ & Reference \\
\hline $\mathrm{Fe}$ & 0.00 & [16] \\
\hline $\mathrm{Fe}^{+2}$ & -21.88 & [16] \\
\hline $\mathrm{Fe}^{+3}$ & -4.11 & [16] \\
\hline $\mathrm{FeC}_{2} \mathrm{O}_{4}$ & -1407.51 & [20] \\
\hline $\mathrm{Fe}\left(\mathrm{C}_{2} \mathrm{O}_{4}\right)_{2}^{2-}$ & -2308.38 & [20] \\
\hline $\mathrm{Fe}\left(\mathrm{C}_{2} \mathrm{O}_{4}\right)_{2}^{1-}$ & -3068.89 & [20] \\
\hline $\mathrm{Fe}\left(\mathrm{C}_{2} \mathrm{O}_{4}\right)_{3}^{3-}$ & -3753.88 & [20] \\
\hline $\mathrm{FeOOH}$ & -117.07 & [21] \\
\hline $\mathrm{Fe}(\mathrm{OH})_{2}$ & -116.39 & [16] \\
\hline $\mathrm{Fe}_{3} \mathrm{O}_{4}$ & -242.65 & [16] \\
\hline $\mathrm{C}_{2} \mathrm{O}_{4}^{-2}$ & +7281.06 & [22] \\
\hline $\mathrm{HC}_{2} \mathrm{O}_{4}^{-}$ & +1541.17 & [22] \\
\hline $\mathrm{H}_{2} \mathrm{C}_{2} \mathrm{O}_{4}$ & -166.52 & [22] \\
\hline $\mathrm{e}^{-}$ & 0.00 & [16] \\
\hline $\mathrm{H}^{+}$ & 0.00 & [16] \\
\hline $\mathrm{H}_{2} \mathrm{O}$ & -56.58 & [16] \\
\hline
\end{tabular}
with oxalic acid [3, 7-9, 16, 18, 19]. These species, along with their respective free energies of formation are shown in Table I.

Table I - Selected species for the construction of thermodynamic stability diagram for the system Oxalic Acid-Iron-Water.

[Tabela I - Espécies selecionadas para construção do diagrama de estabilidade termodinâmica para o sistema Ácido oxálio-Fero-Água.]

Since the stoichiometry for the iron removal process, which includes the reactions that occur between the species shown in Table I is unknown, and because the thermodynamic system to study is expressed in a matrix way, as shown in Equations (A-J), it was developed software under MATLAB (Mathworks) as a calculation tool to solve the equations.

The data obtained in the $\epsilon_{i j}$ matrix, or namely atomic matrix, are shown in Table II. 
Table II - Atomic matrix obtained for the iron, oxalic acid and oxalate system in aqueous solution.

[Tabela II - Matriz atômica obtida para o ferro, do sistema ácido oxálico e oxalato em solução aquosa.]

\begin{tabular}{lcccccc}
\hline \multicolumn{1}{c}{ Specie } & $\begin{array}{c}\text { Specie } \\
\text { number }\left(B_{i}\right)\end{array}$ & $\mathrm{e}^{-}$ & $\mathrm{H}$ & $\mathrm{O}$ & $\mathrm{Fe}$ & $\mathrm{C}_{2} \mathrm{O}_{4}$ \\
\hline $\mathrm{Fe}$ & 1 & 0 & 0 & 0 & 1 & 0 \\
$\mathrm{Fe}^{+2}$ & 2 & -2 & 0 & 0 & 1 & 0 \\
$\mathrm{Fe}^{+3}$ & 3 & -3 & 0 & 0 & 1 & 0 \\
$\mathrm{FeC}_{2} \mathrm{O}_{4}$ & 4 & 0 & 0 & 0 & 1 & 1 \\
$\mathrm{Fe}\left(\mathrm{C}_{2} \mathrm{O}_{4}\right)_{2}^{2-}$ & 5 & 2 & 0 & 0 & 1 & 2 \\
$\mathrm{Fe}\left(\mathrm{C}_{2} \mathrm{O}_{4}\right)_{2}^{-1}$ & 6 & 1 & 0 & 0 & 1 & 2 \\
$\mathrm{Fe}\left(\mathrm{C}_{2} \mathrm{O}_{4}\right)_{3}^{3-}$ & 7 & 3 & 0 & 0 & 1 & 3 \\
$\mathrm{FeOOH}$ & 8 & 0 & 1 & 2 & 1 & 0 \\
$\mathrm{Fe}(\mathrm{OH})_{2}$ & 9 & 0 & 2 & 2 & 1 & 0 \\
$\mathrm{Fe}_{3} \mathrm{O}_{4}$ & 10 & 0 & 0 & 4 & 3 & 0 \\
$\mathrm{C}_{2} \mathrm{O}_{4}^{-2}$ & 11 & 2 & 0 & 0 & 0 & 1 \\
$\mathrm{HC}_{2} \mathrm{O}_{4}^{-}$ & 12 & 1 & 1 & 0 & 0 & 1 \\
$\mathrm{H}_{2} \mathrm{C}_{2} \mathrm{O}_{4}$ & 13 & 0 & 2 & 0 & 0 & 1 \\
$\mathrm{e}^{-}$ & 14 & 1 & 0 & 0 & 0 & 0 \\
$\mathrm{H}^{+}$ & 15 & -1 & 1 & 0 & 0 & 0 \\
$\mathrm{H}_{2} \mathrm{O}$ & 16 & 0 & 2 & 1 & 0 & 0 \\
\hline
\end{tabular}

The system of independent reactions representing the stoichiometry of the iron removal system from kaolin is shown in Table III.

As shown in Table III, a set of 11 independent reactions were obtained explaining either the formation or interaction of each of the species involved in the process. The reactions

Table III - Stoichiometry obtained for iron removal from kaolin system.

[Tabela III - Estequiometria obtida para remoção do ferro do sistema caulim.]

\begin{tabular}{cc}
\hline $\begin{array}{c}\text { Independent } \\
\text { reaction } \\
\left(\rho_{\mathrm{i}}\right)\end{array}$ & Stoichiometry \\
\hline 1 & $\mathrm{Fe} \rightarrow \mathrm{Fe}^{+2}+2 \mathrm{e}^{-}$ \\
2 & $\mathrm{Fe} \rightarrow \mathrm{Fe}^{+3}+3 \mathrm{e}^{-}$ \\
3 & $\mathrm{Fe}^{+2}+\mathrm{C}_{2} \mathrm{O}_{4}^{-2} \rightarrow \mathrm{Fe} \mathrm{C}_{2} \mathrm{O}_{4}$ \\
4 & $\mathrm{Fe}^{+2}+2 \mathrm{C}_{2} \mathrm{O}_{4}^{-2} \rightarrow \mathrm{Fe}\left(\mathrm{C}_{2} \mathrm{O}_{4}\right)_{2}^{2-}$ \\
5 & $\mathrm{Fe}^{+3}+2 \mathrm{C}_{2} \mathrm{O}_{4}^{-2} \rightarrow \mathrm{Fe}\left(\mathrm{C}_{2} \mathrm{O}_{4}\right)_{2}^{1-}$ \\
6 & $\mathrm{Fe}^{+3}+3 \mathrm{C}_{2} \mathrm{O}_{4}^{-2} \rightarrow \mathrm{Fe}\left(\mathrm{C}_{2} \mathrm{O}_{4}\right)_{3}^{3-}$ \\
7 & $\mathrm{Fe}+2 \mathrm{H}_{2} \mathrm{O} \rightarrow \mathrm{FeOOH}+3 \mathrm{H}^{+}+3 \mathrm{e}^{-}$ \\
8 & $\mathrm{Fe}+2 \mathrm{H}_{2} \mathrm{O} \rightarrow \mathrm{Fe}(\mathrm{OH})_{2}+2 \mathrm{H}^{+}+2 \mathrm{e}^{-}$ \\
9 & $3 \mathrm{Fe}+4 \mathrm{H}_{2} \mathrm{O} \rightarrow \mathrm{Fe}_{3} \mathrm{O}_{4}+8 \mathrm{H}^{+}+8 \mathrm{e}^{-}$ \\
10 & $\mathrm{H}_{2} \mathrm{C}_{2} \mathrm{O}_{4} \rightarrow \mathrm{H}^{+}+\mathrm{HC}_{2} \mathrm{O}_{4}^{-}$ \\
11 & $\mathrm{HC}_{2} \mathrm{O}_{4}^{-} \rightarrow \mathrm{H}^{+}+\mathrm{C}_{2} \mathrm{O}_{4}^{-2}$ \\
\hline
\end{tabular}

1 to 3 and 7 to 11 coincide with previous results found in the literature $[3,7-9,16,18,19]$. However, in order to express an independent stoichiometric system, it is not necessary that the whole 11 reactions result equivalent to the mechanisms found experimental data for iron removal, since changes in free energy will be equal due to mass conservation [15-17].

For each species it was calculated the overall thermodynamic stability $\left(\Sigma_{\mathrm{i}}\right)$, as a function of $\mathrm{pH}$ and redox potential $E_{h}$, employing the developed software in MATLAB and applying the matrix expression as shown in Equation (I). These calculations assume liquid solution close to ideality, which is a good approximation to these systems, under the iron concentration in solution after removal, as shown in multiple experiments for iron removal [20]. The thermodynamic stability is reported as a linear function of three parameters a, b, c, as shown in Equation (L).

$$
\Sigma_{\mathrm{i}}=\mathrm{a}(\mathrm{pH})+\mathrm{b}\left(\mathrm{E}_{\mathrm{h}}\right)+\mathrm{c}
$$

The results obtained in the calculation of the overall stability parameters for each species are shown in Table IV.

By calculating stability functions it is possible to estimate an overall thermodynamic stability diagram for the selected species. According to Fishtik [16], a species is considered stable if its overall stability is negative. In the case of two or even three species in equilibrium, their global stabilities, as the thermodynamic theory, should be equal, negative and lower than other species at a defined $\mathrm{pH}$ and $\mathrm{E}_{\mathrm{h}}[16]$, but correlated with the minimization of free energies of each of the reactions previously described in Table II.

Table IV - Calculation of overall stability parameters for each species in the iron removal system.

[Tabela IV - Cálculo geral dos parâmetros de estabilidade para cada espécie no sistema de remoção do ferro.]

\begin{tabular}{lccc}
\hline \multicolumn{1}{r}{ Specie } & A & B & C \\
\hline $\mathrm{Fe}$ & 0.1167 & 2.3964 & 4.5059 \\
$\mathrm{Fe}^{+2}$ & 0.1167 & 0.3964 & 3.5571 \\
$\mathrm{Fe}^{+3}$ & 0.1167 & -0.6036 & 4.3276 \\
$\mathrm{FeC}_{2} \mathrm{O}_{4}$ & 0.0615 & 0.5200 & -2.3316 \\
$\mathrm{Fe}\left(\mathrm{C}_{2} \mathrm{O}_{4}\right)_{2}^{2-}$ & 0.0615 & 0.5200 & -41.3973 \\
$\mathrm{Fe}\left(\mathrm{C}_{2} \mathrm{O}_{4}\right)_{2}^{1-}$ & 0.0062 & -0.3564 & -20.1779 \\
$\mathrm{Fe}\left(\mathrm{C}_{2} \mathrm{O}_{4}\right)_{3}^{3-}$ & -0.0490 & -0.2327 & 4.3163 \\
$\mathrm{FeOOH}$ & -0.0606 & -0.6036 & 4.3450 \\
$\mathrm{Fe}(\mathrm{OH})_{2}$ & -0.0015 & 0.3964 & 4.3745 \\
$\mathrm{Fe} \mathrm{O}_{4}$ & -0.1227 & -0.8109 & 12.8268 \\
$\mathrm{C}_{2} \mathrm{O}_{4}^{-2}$ & -0.0552 & 0.1236 & 23.9049 \\
$\mathrm{HC}_{2} \mathrm{O}_{4}^{-}$ & 0.0039 & 0.1236 & 23.6525 \\
$\mathrm{H}_{2} \mathrm{C}_{2} \mathrm{O}_{4}$ & 0.0630 & 0.1236 & 23.5784 \\
\hline
\end{tabular}

Using the developed software in MATLAB, and following the criterion of stability described above, it was built the overall thermodynamic stability diagram for the system Oxalic Acid-Iron in aqueous solution. The diagram is shown in Fig. 1. 


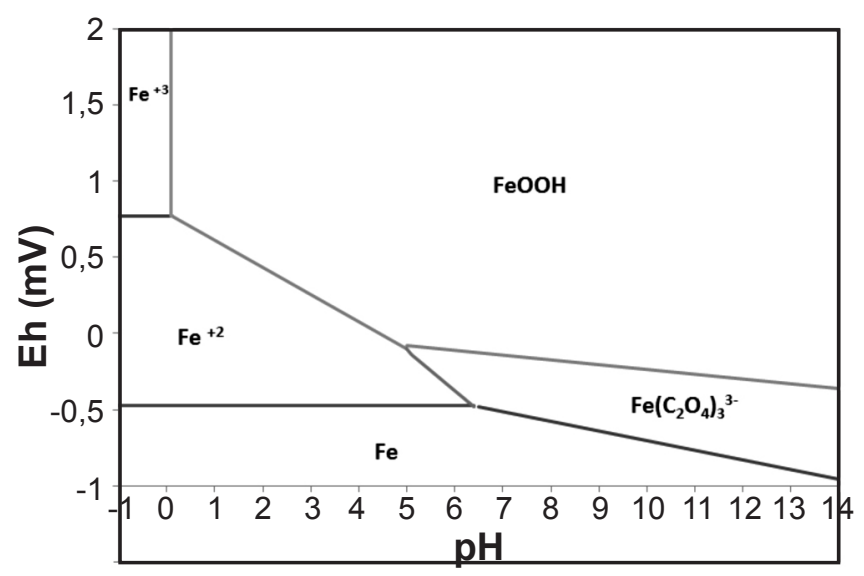

Figure 1: Overall thermodynamic stability diagram obtained for the system oxalic acid-iron-water.

[Figura 1: Diagrama geral de estabilidade termodinâmica do sistema ácido oxálico-ferro-água.]

As shown in Fig. 1, the obtained thermodynamic stability diagram shows how the most stable species in iron removal from kaolin process is soluble iron oxalate $\mathrm{Fe}\left(\mathrm{C}_{2} \mathrm{O}_{4}\right)_{3}^{3-}$, which agrees with experimental results found by Lema [8], $\mathrm{Fe}^{3+}$ is only stable at low $\mathrm{pH}$ levels, which include levels from -1 to 0 , therefore it is not likely to find this species during iron removal because it occurs normally under $\mathrm{pH}$ between 1 3 , the most probable is this molecule forming a trioxalate, generating a stable molecule. A stability region for other species of iron oxalate was not found, for example species such as $\mathrm{Fe}^{2+}$; additionally it was verified the low probability of forming insoluble species such as iron oxalate $\mathrm{FeC}_{2} \mathrm{O}_{4}$.

The absence of the species of oxalic acid, $\mathrm{H}_{2} \mathrm{C}_{2} \mathrm{O}_{4}, \mathrm{HC}_{2} \mathrm{O}_{4}^{-}$, $\mathrm{y}_{2} \mathrm{O}_{4}^{2-}$ in the diagram shows that these alone are critical to the processes of dissolution, by providing exclusively ions $\mathrm{H}^{+}$and becoming relevant when forming a species complex with iron. It is consistent with the reported mechanism of dissolution of iron [7].

\section{CONCLUSIONS}

The most stable species of soluble iron oxalate is $\mathrm{Fe}\left(\mathrm{C}_{2} \mathrm{O}_{4}\right)_{3}^{3-}$ with a free energy of formation calculated of $-3753.88 \mathrm{kcal} / \mathrm{mol}$. Stability for this specie was found between $\mathrm{pH} 5.5$ to 14 and $\mathrm{E}_{\mathrm{h}}$ between -1 to 0 . The overall stability assessment showed that this species is the only oxalate in equilibrium with other iron compounds associated with the removal of iron in kaolin.

\section{REFERENCES}

[1] F. G Colina, S. Esplugas, J. Costa, High-Temperature Reaction of Kaolin with Sulfuric Acid, Ind. Eng. Chem. Res. 17 (2002) 4168-4173.

[2] Roskill Information Services, "The economics of kaolin", London, UK (2006).

[3] F. Veglio, Factorial experiments in the development of a kaolin bleaching process using thiourea in sulphuric acid solutions, Hydrometallurgy 45 (1997) 181-197.

[4] M. Önal, Y. Sarıkaya, Some physicochemical properties of a clay containing smectite and palygorskite, Appl. Clay Sci. 44 (2009) 161-165.

[5] F. Veglió, F. Beolchini, "Development of an Iron Removal Process from Kaolin by Thiourea Leaching: Kinectic and Related Statistical Analysis", in: P. M. Editor, XXI Int. Mineral Processing Cong., Rome, Italy, Elsevier Inc. (2000) pp. 36-42.

[6] S. Lee, T. Tran, Y. Park, S. Kim, M. Kim, Study on the kinetics of iron oxide leaching by oxalic acid, Int. J. Mineral Proc. 80 (2006) 144-152.

[7] D. Panias, Mechanisms of dissolution of iron oxides in aqueous oxalic acid solutions, Hydrometallurgy 42 (1996) 257-265.

[8] J. M. Lema, C. Cameselle, M. T. Ricart, M. J. Nu, Iron removal from kaolin, Comparison between "in situ” and “two-stage”, Bioleaching Proc. 68 (2003) 97-105.

[9] C. Cameselle, M. José Núñez, J. M. Lema, J. Pais, Leaching of iron from kaolins by a spent fermentation liquor: Influence of temperature, $p H$, agitation and citric acid concentration, J. Ind. Microbiology 14 (1995) 288-292. [10] L. M. S. D. Mesquita, T. Rodrigues, S. S. Gomes, Bleaching of Brazilian kaolins using organic acids and fermented medium, Minerals Eng. 9 (1996) 965-971.

[11] M. Hosseini, M. Pazouki, M. Ranjbar, M. Habibian, Bioleaching of iron from highly contaminated kaolin clay by Aspergillus niger, Appl. Clay Sci. 37 (2007) 251-257.

[12] E. Aghaie, M. Pazouki, M. R. Hosseini, M. Ranjbar, F. Ghavipanjeh, Response surface methodology (RSM) analysis of organic acid production for Kaolin beneficiation by Aspergillus niger, Chem. Eng. J. 147 (2009) 245-251.

[13] K. G. Bhattacharyya, S. S. Gupta, Adsorption of a few heavy metals on natural and modified kaolinite and montmorillonite: a review, Adv. Colloid Interf. Sci. 2 (2008) 114-131.

[14] M.-qin Jiang, Q.-ping Wang, X.-ying Jin, Z.-liang Chen, Removal of Pb(II) from aqueous solution using modified and unmodified kaolinite clay, J. Hazardous Mater. 170 (2009) 332-339.

[15] I. Fishtik, Thermodynamic stability of chemical species in multiple reaction systems, J. Phys. Chem. B 9 (2005) 3851-9.

[16] I. Fishtik, Thermodynamic stability relations in redox systems, Environmental Sci. Tech. 6 (2006) 1902-10.

[17] I. Fishtik, R. Datta, A General Thermodynamic and Stoichiometric Theory of Stability of Chemical Species, J. Phys. Chem. A 108 (2004) 5727-5739.

[18] D. Panias, Dissolution of hematite in acidic oxalate solutions: the effect offerrous ions addition, Hydrometallurgy 43 (1996) 219-230.

[19] S. Lee, T. Tran, B. Jung, S. Kim, M. Kim, Dissolution of iron oxide using oxalic acid, Hydrometallurgy 87 (2007) 91-99.

[20] C. Ocampo López, Estudio Termodinámico de la Remoción de Hierro Presente en Caolín, Thesis Dr. (Doctorado en Ingeniería), Universidad Pontificia 
Bolivariana (2011) pp.141.

[21] R. H. Perry, D. W. Green, "Perry's Chemical Engineers' Handbook", in: 1. USA: Mc Graw Hill (1997) pp. 370.
[22] M. Uchimiya, A. Stone, Redox reactions between iron and quinones: Thermodynamic constraints, Geochim. Cosmochim. Acta 70 (2006) 1388-1401.

(Rec. 21/06/2012, Ac. 11/11/2012) 